\title{
Effect of spraying some plant oils and green tea extract on fruit setting, yield and fruit quality of Barhee date palms grown under Aswan region conditions
}

\author{
Abdel Aal, A.M.K. ${ }^{1,2}$, F.H. Abdelaziz², F.F. Ahmed ${ }^{2}$, A.Y. Mohamed ${ }^{3}$ and Sahar A. Abdel-Halim ${ }^{3 *}$ \\ ${ }^{1}$ Faculty of Meteorology, Environment and Arid Land Agriculture, King Abdulaziz University, Jeddah, Saudi \\ Arabia \\ ${ }^{2}$ Horticulture Department, Faculty of agriculture, Minia University, Minia, Egypt \\ ${ }^{3}$ Tropical Fruits Department, Horticulture Research Institute, ARC, Egypt
}

\begin{abstract}
The present investigation was carried out during 2017 and 2018 seasons. Barhee date palms grown under Aswan region conditions and produced via tissue culture received three sprays of four plant extracts namely oils of moringa, garlic and onion and extract of green tea each at 0.05 to $0.2 \%$. The merit was elucidating the effect of these plant extracts on fruiting setting, yield and fruit quality. Carrying out three sprays of plant extract oils moringa, garlic, onion and green tea extract each 0.05 to $0.2 \%$ had an announced promotion on fruiting setting, yield and fruit quality relative to the control treatment. Using plant extracts of green tea extract, oils of moringa, onion and garlic in ascending order was very effective in promoting fruiting setting, yield and fruit quality. Meaningless stimulation on these characteristics were observed among the higher two concentrations of each plant extracts namely 0.1 and $0.2 \%$ for promoting on fruiting setting, yield and fruit quality of Barhee date palms, it is suggested to spray garlic oil at $0.1 \%$ three times before pollination (in the first week of March), just after fruit setting (middle of April) and one month later (middle of May).
\end{abstract}

Keywords: Barhee date palms; Phytogenic; fruit setting; yield; fruit quality.

\section{Introduction}

Recently, using plant extracts especially oils was the new alternative for improving of the date palms all growth aspects, production as well as enhancing fruit quality and marketing. The higher content of plant extracts from nutrients, amino acids, vitamins, antioxidants, plant pigments, phenolic compounds and volatile oils encourage the need for further studies towards their positive action on fruiting of fruits crops (Srimal, 1997 and Martos et al., 2007). Previous studies showed

\footnotetext{
*Corresponding author: Sahar A. Abdel-Halim

Email: wonderful.story34_2019@yahoo.com

Received: February 6, 2021.

Accepted: March 27, 2021.

Published: April 1, 2021.
}

that treating Zaghloul date palms (Refaai, 2014), citrus (Cairney, 1995), wonderful pomegranates (Ahmed and Gad El- Kareem, 2014), Washington Navel oranges (ElKhawaga and Mansour, 2014, Ahmed and Habasy- Randa, 2014 and Abd El-Rahman, 2015), Barhee date palms (Ahmed, 2016) and Balady mandarin (Ahmed and Habasy- Randa, 2017). The target of this study as examining the effect of four plant extracts namely green tea extracts as well as oils of moringa, garlic and onion on fruit setting, yield and fruit quality of Barhee date palms growing under Aswan region. 


\section{Materials and Methods}

This study was carried out during 2017 and 2018 seasons on 39 tree uniform in vigour 18 years old tissue culture derived off short of Barhee date palms were selected for achieving this study. The palms are grown in Kom Ombo district Aswan Governorate.
The palms were planted at $7.0 \times 7.0$ meters. The structure of soil is silty clay with a water table depth not less than two meters. It is irrigated through surface irrigation system using Nile water. Soil analysis was carried out using the procedures outlined according to (Black et al., 1965).

Table (1): Mechanical, physical and chemical analysis of the tested orchard soil

\begin{tabular}{|c|c|}
\hline Constituents & Values \\
\hline \multicolumn{2}{|l|}{ Particle size distribution } \\
\hline Sand \% & 9.75 \\
\hline Silt \% & 58.50 \\
\hline Clay $\%$ & 31.75 \\
\hline Texture grade & Silty clay \\
\hline $\mathrm{pH}(1: 2.5$ extract $)$ & 7.88 \\
\hline E.C. $(1: 2.5$ extract $)\left(\mathrm{mmhos} / 1 \mathrm{~cm} / 25^{\circ} \mathrm{C}\right)$ & 0.93 \\
\hline O.M. $\%$ & 1.98 \\
\hline $\mathrm{CaCO}_{3} \%$ & 1.11 \\
\hline \multicolumn{2}{|l|}{ Macronutrients values } \\
\hline Total N \% & 0.12 \\
\hline P (Olsen methods, ppm) & 22.0 \\
\hline $\mathrm{K}$ (ammonium acetate, ppm) & 410.0 \\
\hline $\mathrm{Mg}(\mathrm{ppm})$ & 81.0 \\
\hline $\mathrm{S}(\mathrm{ppm})$ & 5.8 \\
\hline \multicolumn{2}{|l|}{ EDTA extractable micronutrients (ppm) } \\
\hline $\mathrm{Zn}$ & 2.05 \\
\hline $\mathrm{Fe}$ & 10.10 \\
\hline $\mathrm{Mn}$ & 9.88 \\
\hline
\end{tabular}

The palms are hand pollinated by inserting five strands for each spathe after two days of female cracking and received the common horticultural practices that already applied in the orchard number of bunches was adjusted to ten. The experiment included the following thirteen treatments:

1- Control (spraying with water).

2- Spraying moringa oil at $0.05 \%(0.5 \mathrm{ml} /$ L).

3- Spraying moringa oil at $0.1 \%(1.0 \mathrm{ml} / \mathrm{L})$.

4- Spraying moringa oil at $0.2 \%(2.0 \mathrm{ml} / \mathrm{L})$.

5- Spraying garlic oil at $0.05 \%(0.5 \mathrm{ml} / \mathrm{L})$.

6- Spraying garlic oil at $0.1 \%(1.0 \mathrm{ml} / \mathrm{L})$.

7- Spraying garlic oil at $0.2 \%(2.0 \mathrm{ml} / \mathrm{L})$.

8- Spraying onion oil at $0.05 \%(0.5 \mathrm{ml} / \mathrm{L})$.

9- Spraying onion oil at $0.1 \%(1.0 \mathrm{ml} / \mathrm{L})$.
10- Spraying onion oil at $0.2 \%(2.0 \mathrm{ml} / \mathrm{L})$.

11 - Spraying green tea extract at $0.05 \%(0.5$ $\mathrm{g} / \mathrm{L}$ ).

12- Spraying green tea extract at $0.1 \%(1.0 \mathrm{~g} /$ L).

13- Spraying green tea extract at $0.2 \%(2.0 \mathrm{~g} /$ L).

Spraying was done three times (before hand pollination, just after fruits setting and at one month later. Triton B as wetting agent was added at 0.05 to all solution praying. Plant extracts analysis of green tea extract as well as oils of moringa, garlic and onion are given in Tables $(2,3,4,5)$. 
Table (2): Chemical analysis of green tea extract (according to Lee et al., 2015)

\begin{tabular}{ll}
\hline Constituent & \multicolumn{1}{c}{ values } \\
\hline Total carbohydrate & $11.0 \mathrm{~g}$ \\
Total fats & $0.4 \mathrm{~g}$ \\
Favonoides & $0.3 \mathrm{~g}$ \\
Tannins & $2.9 \mathrm{~g}$ \\
Flour & $20.0 \mathrm{mg}$ \\
$\mathrm{N}$ & $1.19 \mathrm{~g}$ \\
$\mathrm{P}$ & $0.24 \mathrm{~g}$ \\
$\mathrm{~K}$ & $1.0 \mathrm{~g}$ \\
Magnesium & $0.5 \mathrm{~g}$ \\
Zinc & $41.0 \mathrm{mg}$ \\
Fe & $51.0 \mathrm{mg}$ \\
Mn & $60.0 \mathrm{mg}$ \\
Coneshin & $0.7 \mathrm{~g}$ \\
Thiamine & $110.0 \mathrm{mg}$ \\
Vitamin A & $90.0 \mathrm{mg}$ \\
Vitamin B & $74.1 \mathrm{mg}$ \\
Vitamin C & $120.0 \mathrm{mg}$ \\
Coffeic acid & $315.0 \mathrm{mg}$ \\
\hline
\end{tabular}

Table (3): Chemical composition of moringa oil (Moringa oleifera) Mnayer et al., 2014)

\begin{tabular}{lc}
\hline Constituent & Values \\
\hline 1- Vitamins (mg/ 100 g F.W.) & 1500.0 \\
Beta-carotene & 500.0 \\
E & 900.0 \\
$\mathrm{~A}$ & 902.0 \\
$\mathrm{~B}_{1}$ & 7.1 \\
$\mathrm{~B}_{2}$ & 180.0 \\
$\mathrm{C}$ & 250.0 \\
$\mathrm{~K}$ & \\
2- Minerals (mg/ 100 g F.W.) & 900.0 \\
Ca & 500.0 \\
$\mathrm{~K}$ & 900.0 \\
$\mathrm{~N}$ & 130.0 \\
$\mathrm{P}$ & 199.0 \\
Mg & \\
3-Amino acids (mg/ 100 g F.W.) & 83.9 \\
Phenylalanine & 75.0 \\
Lysine & 89.9 \\
Leucine & 65.0 \\
Threonine & 66.0 \\
Isoleucine & 66.0 \\
Arginine & 28.0 \\
Cysteine & 36.0 \\
Methionine & 33.0 \\
Tryptophan &
\end{tabular}


Abdel Aal et al., : SVU-International Journal of Agricultural Sciences, 3 (2): 12-21, 2021

Table (4): Chemical composition of onion oil. Mnayer et al., 2014)

\begin{tabular}{lc}
\hline Constituent & Values (mg/ 100 g D.W.) \\
\hline 1- Propenyl propyl disulfide a & 7.26 \\
Methyl propyl trisulfide & 5.20 \\
Menthone & 0.34 \\
Dimethyl tetrasulfide & 0.15 \\
Dipropyl trisulfide & 17.10 \\
Eugenol & 3.07 \\
2- Methyl -3, 4-dithiaheptane & 6.48 \\
Dipropyte trisulfide & 0.55 \\
Dipropyl disulfide & 30.92 \\
Allyl propyl sulfide & 0.42 \\
Dimethyl trisulfide & 0.30 \\
\hline
\end{tabular}

Table (5): Chemical composition of garlic oil (according to Mnayer et al., 2014)

\begin{tabular}{lc}
\hline Constituent & $\begin{array}{c}\text { Values } \\
(\mathrm{mg} / 100 \mathrm{~g} \text { D.W. })\end{array}$ \\
\hline Dipropyl disulfide & 0.25 \\
Diallyl disulfide & 37.90 \\
Dimethyl trisulfide & 0.33 \\
Dimethyl thiophene & 0.08 \\
Allyl methyl disulfide & 3.69 \\
Methyl propyl disulfide & 0.25 \\
Methyl 1- propenyl disulfide a & 0.46 \\
Allyl propyl sulfide & 0.09 \\
Bis-)1- propenyl) - sulfide a & 0.08 \\
Diallyl sulfide & 6.59 \\
Dimethyl disulfide & 0.15 \\
Allyl methyl teterosulfide & 1.07 \\
Allyl propyl trisulfide & 0.23 \\
Dially trisulfide & 28.06 \\
Eugenal & 0.23 \\
\hline
\end{tabular}

Randomized complete block design (RCBD) was adopted which the experiment included thirteen treatments and each treatment was replicated three times, one palm per each.

During both seasons the following measurements were recorded:

1- Percentages of initial fruit setting and fruit retention.

2- Yield and bunch weight. The yield of each palm was recorded in terms of weight per bunch (kg.) and multiplying the average bunch weight $(\mathrm{kg}$.$) by total number of$ bunches per palm (ten bunches).
3- Physical and chemical characters of the fruit namely fruit weight (g.), fruit dimensions (height, diameter), percentages of seeds and flesh, T.S.S. \%, total, reducing and non - reducing sugars (Lane and Eynon,1965), total acidity and total fibre \% (A.O.A.C., 2000).

Statistical analysis was done according to (Snedecor and Cochran, 1980) New L.S.D. test at $5 \%$ was used for made all comparisons among different treatment means. 


\section{Results and Discussion}

\section{1- Percentages of initial fruit setting fruit retention and yield per palm}

Data in Tables (6) noticeably declare that treating Barhee date palms three times with plant extracts, namely oils of moringa, garlic oil, onion and green tea extract at 0.05 to $0.2 \%$ had significant promotion on the percentages of initial fruit setting and fruit retention, bunch weight, bunch length and yield / palm relative top the control treatment. The promotion was significantly associated with using plant extracts of garlic oil, onion oil, moringa oil and green tea extract in descending order. The promotion on the yield was depended on increasing concentrations of each plant extracts. Increasing concentrations from 0.1 to $0.2 \%$ failed to show significant promotion on the percentage to initial fruit setting and fruit retention, bunch weight, bunch length and yield/ palm. Therefore, from economical point of view it is concluded to use the medium concentrations of each plant extract namely $0.1 \%$. Under the promised treatment (using garlic oil at 0.1 ), the yield per palm reached $(181.0, \quad 183.0 \mathrm{~kg})$ during both seasons respectively. The percentage of increment on the yield over the control treatment $(57.4 \&$ $55.1 \%$ ) reached 2017 and 2018 seasons, respectively. These results were true during both seasons.

\section{2-Fruit quality}

It is clear from the data in Tables $(7,8)$ that subjecting Barhee date palms three times with any one of four plant extracts (oils of moringa, garlic, onion and green tea extract) each at 0.05 to $0.2 \%$ significantly was followed by enhancing fruit quality in terms of increasing fruit weight, height and diameter of fruit, percentages of seed and flesh weight, T.S.S. $\%$, total, reducing, non - reducing sugars and decreasing total acidity $\%$ and total fibre crude $\%$ relative to the check treatment.
The promotion on both physical and chemical characteristics of the fruits was significantly associated with using plant extracts of green tea extract, moringa oil, onion oil and garlic oil in ascending order. This means that the best plant extracts was garlic oil followed by onion oil and green tea extract occupied the last position in this respect. The promotion also on fruit quality was in proportional to the increase in concentration of each plant extract. Meaningless promotion on fruit quality was attribute to increasing concentrations of each plant extracts from 0.1 to $0.2 \%$. Therefore, economical point of view, it is advised to using the medium concentrations of each plant extracts namely $0.1 \%$. The best results were obtained due to treating the palms three times with garlic oil at $0.1 \%$ unfavourable effects on fruit quality were recorded on untreated palms. Fruit shape values was unaffected by the investigated plant extracts treatments. These results true during both seasons.

\section{DISCUSSION}

Plant extracts namely moringa oil, garlic oil, onion oil and green tea extract. The higher amounts of vitamins, nutrients, amino acids, antioxidant, tannins, pigments, sulphur, Fatty acids, Coffeic acid, capsicum and nigella one caused explain the present results (Kirtikar and Basu, 1984) and Peter, 1999). The results are in harmony with those obtained by (Ahmed et al., 2013); Mohamed and Mohamed (2013); Al- Wasfy et al., (2013); Ahmed and Gad El Kareem (2014); Abada (2014); Uwakiem (2014); Refaai (2014); Abd El-Rahman (2015); Hegazy (2015); Ahmed (2016); El- Salhy et al., (2017) and Abd ElLatif (2018). For promoting yield and fruit quality of Barhee date palms is suggested to spray garlic oil at $0.1 \%$ three times before hand pollination (first week of March), just after fruits setting (middle of April) and one month later (middle of may). 
Abdel Aal et al., : SVU-International Journal of Agricultural Sciences, 3 (2): 12-21, 2021

Table (6): Effect of spraying oils of moringa, garlic and onion and extract of green tea on initial fruit setting the percentage of fruit retention, bunch weight and length and yield /palm (kg.) of Barhee date palms during 2017 and 2018 seasons.

\begin{tabular}{|c|c|c|c|c|c|c|c|c|c|c|}
\hline \multirow[t]{2}{*}{ Treatments } & \multicolumn{2}{|c|}{$\begin{array}{l}\text { Initial fruit } \\
\text { setting } \%\end{array}$} & \multicolumn{2}{|c|}{ Fruit retention $\%$} & \multicolumn{2}{|c|}{$\begin{array}{c}\text { Bunch weight } \\
\text { (kg.) }\end{array}$} & \multicolumn{2}{|c|}{$\begin{array}{l}\text { Bunch length } \\
(\mathrm{cm})\end{array}$} & \multicolumn{2}{|c|}{$\begin{array}{l}\text { Yield/ palm } \\
\quad \text { (kg.) }\end{array}$} \\
\hline & 2017 & 2018 & 2017 & 2018 & 2017 & 2018 & 2017 & 2018 & 2017 & 2018 \\
\hline 2-Spraying moringa oil at $0.05 \%$ & 60.0 & 60.4 & 44.0 & 44.4 & 13.4 & 13.5 & 120.0 & 121.0 & 134.0 & 135.0 \\
\hline 3- Spraying moringa oil at $0.1 \%$ & 62.4 & 62.9 & 45.8 & 46.0 & 15.3 & 15.5 & 123.2 & 124.0 & 153.0 & 155.0 \\
\hline 5- Spraying garlic oil at $0.05 \%$ & 66.0 & 66.3 & 50.2 & 50.9 & 17.4 & 17.5 & 126.1 & 126.6 & 174.0 & 175.0 \\
\hline 6- Spraying garlic oil at $0.1 \%$ & 67.2 & 67.5 & 53.4 & 54.2 & 18.1 & 18.3 & 128.3 & 129.0 & 181.0 & 183.0 \\
\hline 7- Spraying garlic oil at $0.2 \%$ & 67.5 & 67.8 & 54.4 & 55.0 & 18.3 & 18.5 & 128.5 & 130.0 & 183.0 & 185.0 \\
\hline 8- Spraying onion oil at $0.05 \%$ & 63.6 & 63.9 & 47.1 & 47.4 & 16.2 & 16.3 & 124.0 & 124.3 & 162.0 & 163.0 \\
\hline 12- Spraying green tea extract at $0.1 \%$ & 58.3 & 58.9 & 42.9 & 43.3 & 12.9 & 13.1 & 119.0 & 119.5 & 129.0 & 131.0 \\
\hline 13- Spraying green tea extract at $0.2 \%$ & 59.0 & 59.5 & 43.4 & 43.7 & 13.1 & 13.3 & 119.3 & 120.0 & 131.0 & 133.0 \\
\hline New L.S.D. at $5 \%$ & 2.1 & 1.9 & 1.3 & 1.4 & 1.0 & 1.0 & 1.6 & 1.7 & 5.9 & 5.5 \\
\hline
\end{tabular}


Abdel Aal et al., : SVU-International Journal of Agricultural Sciences, 3 (2): 12-21, 2021

Table (7): Effect of spraying oils of moringa, garlic and onion and extract of green tea on some physical characteristics of Barhee date palms during 2017 and 2018 seasons.

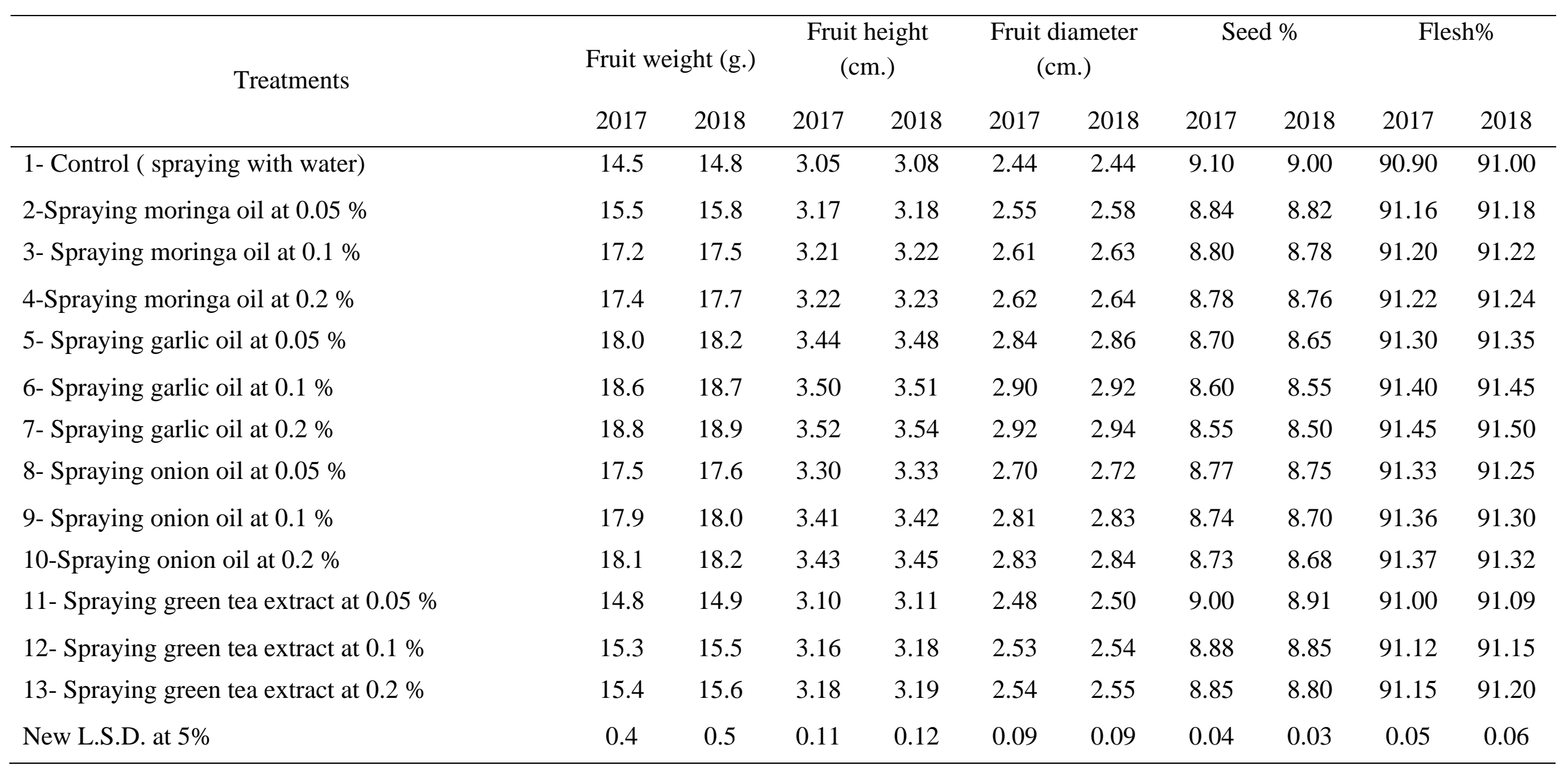


Abdel Aal et al., : SVU-International Journal of Agricultural Sciences, 3 (2): 12-21, 2021

Table (8): Effect of spraying oils of moringa, garlic and onion and extract of green tea on some chemical characteristics of the fruits of Barhee date palms during 2017 and 2018 seasons.

\begin{tabular}{|c|c|c|c|c|c|c|c|c|c|c|c|c|}
\hline \multirow{2}{*}{ Treatments } & \multicolumn{2}{|c|}{ T.S.S.\% } & \multicolumn{2}{|c|}{ Total sugars\% } & \multicolumn{2}{|c|}{$\begin{array}{l}\text { Reducing } \\
\text { sugars } \%\end{array}$} & \multicolumn{2}{|c|}{$\begin{array}{l}\text { Non-reducing } \\
\text { sugars } \%\end{array}$} & \multicolumn{2}{|c|}{ Total acidity\% } & \multicolumn{2}{|c|}{$\begin{array}{c}\text { Total fibre } \\
\text { crude } \%\end{array}$} \\
\hline & 2017 & 2018 & 2017 & 2018 & 2017 & 2018 & 2017 & 2018 & 2017 & 2018 & 2017 & 2018 \\
\hline 1- Control ( spraying with water) & 28.0 & 28.0 & 22.9 & 23.0 & 16.4 & 16.5 & 6.5 & 6.5 & 0.250 & 0.244 & 2.00 & 1.95 \\
\hline 2-Spraying moringa oil at $0.05 \%$ & 29.5 & 29.8 & 24.2 & 24.5 & 17.5 & 17.8 & 6.7 & 6.7 & 0.210 & 0.205 & 1.70 & 1.65 \\
\hline 3- Spraying moringa oil at $0.1 \%$ & 30.3 & 30.5 & 24.8 & 25.0 & 18.1 & 18.3 & 6.7 & 6.7 & 0.190 & 0.185 & 1.50 & 1.48 \\
\hline 4-Spraying moringa oil at $0.2 \%$ & 30.5 & 30.7 & 25.0 & 25.3 & 18.4 & 18.5 & 6.6 & 6.8 & 0.188 & 0.180 & 1.45 & 1.40 \\
\hline 5- Spraying garlic oil at $0.05 \%$ & 32.0 & 32.3 & 26.5 & 26.6 & 19.2 & 19.3 & 7.3 & 7.3 & 0.160 & 0.155 & 1.10 & 1.05 \\
\hline 6- Spraying garlic oil at $0.1 \%$ & 32.9 & 33.4 & 27.3 & 27.5 & 19.6 & 19.7 & 7.7 & 7.8 & 0.145 & 0.140 & 0.90 & 0.88 \\
\hline 7- Spraying garlic oil at $0.2 \%$ & 33.3 & 33.9 & 27.5 & 27.8 & 19.8 & 20.0 & 7.7 & 7.9 & 0.140 & 0.134 & 0.88 & 0.85 \\
\hline 8- Spraying onion oil at $0.05 \%$ & 31.0 & 31.3 & 25.3 & 25.7 & 18.5 & 18.6 & 6.8 & 7.1 & 0.180 & 0.175 & 1.40 & 1.33 \\
\hline 9- Spraying onion oil at $0.1 \%$ & 31.7 & 31.9 & 26.0 & 26.3 & 19.0 & 19.1 & 7.0 & 7.2 & 0.165 & 0.160 & 1.28 & 1.21 \\
\hline 10 -Spraying onion oil at $0.2 \%$ & 31.9 & 32.3 & 26.3 & 26.5 & 19.2 & 19.3 & 7.1 & 7.3 & 0.160 & 0.155 & 1.20 & 1.15 \\
\hline 11- Spraying green tea extract at $0.05 \%$ & 28.5 & 28.7 & 23.2 & 23.4 & 16.6 & 16.8 & 6.6 & 6.6 & 0.240 & 0.233 & 1.98 & 1.90 \\
\hline 12- Spraying green tea extract at $0.1 \%$ & 29.1 & 29.3 & 23.7 & 23.8 & 17.1 & 17.1 & 6.6 & 6.7 & 0.228 & 0.220 & 1.80 & 1.75 \\
\hline 13- Spraying green tea extract at $0.2 \%$ & 29.2 & 29.4 & 23.9 & 24.0 & 17.3 & 17.2 & 6.6 & 6.8 & 0.225 & 0.215 & 1.75 & 1.68 \\
\hline New L.S.D. at $5 \%$ & 0.5 & 0.6 & 0.4 & 0.5 & 0.5 & 0.5 & 0.1 & 0.1 & 0.045 & 0.040 & 0.13 & 0.14 \\
\hline
\end{tabular}




\section{REFERENCES}

Abada, M.A.M. (2014) 'A comparative study for the effect of green tea extract and some antioxidants on Thompson seedless grapevines' Inter. J. of Plant \& Soil Sci. 3(10): pp. 1333-1342

Abd El- Rahman, M.M.A. (2015) 'Yield and fruit quality of Washington navel oranges as influenced by foliar application of fenugreek and rocket seed sprouts' World Rural Observations. 7 (2):pp.99-104.

Abdel- Latif, M.M. (2018) 'Effect of spraying salicylic acid and some plant extracts on fruiting of Superior grapevines' $P h$. Thesis Fac. of Agric. Minia Univ. Egypt.

Ahmed, E.F.S. (2016) 'Impact of spraying Moringa oil and turmeric extract on fruiting of Barhee date palms J. Biol' Chem. Environ. Sci. 11(3):pp. 359- 365.

Ahmed, F.F. and Gad El- Kareem, R.M. (2014) 'Effect of spraying wheat seed sprout and some nutrients on fruiting of wonderful pomegranate trees' World Rural Observation. 6(4): pp.115-120.

Ahmed, F.F. and Habasy- Randa, E.Y. (2017) 'Response of Balady mandarin trees to spraying some plant extracts. J. Biol' Chem. Environ. Sci. 12(1): pp.523-544.

Ahmed, F.F. and Habasy- Randa, E.Y. (2014) 'Productive performance of Washington Navel orange trees in relation to foliar application of barley seed sprout and royal Jelly' World Rural Observations. 6 (4): pp. 109-114.

Ahmed, F.F., Mansour, A.M., Montasser, M.A.A., Merwad, M.A. and Mostafa, E.A.M. (2013) 'Response of Valencia orange trees to foliar application of Roselle, turmeric and seaweed extracts' J. of Applied Science Research. 9 (1):pp. 960-969.
Al-Wasfy, M.M., Ahmed, F.F. and El- Masry, A.M. (2013) 'Behaviour of Washington Navel orange Trees to foliar application of some plant extracts' Hort. Science Journal of Suez Canal Univ. Vol. 1:pp. 281-285.

Association of Official Agricultural Chemists (2000) 'Official Method of Analysis (A.P.A.C.) $15^{\text {th }}$ Ed., Published by A.O.A.C' Washington, D,C. ( U.S.A.) pp. 490-510.

Black, C.V., Evans, D., Ersminger, L.E. White, J.L. and Clark, F.E. (1965) 'Methods of Soil Analysis. Amer. Soc. Agron Inc. Bull' Medison, Wisconsin, U.S.A. pp. 8911400.

Cairney, E. (1995) 'Sprouts (Handbook Argyll publishing Glen drangel Sargyl PA' $223 A E$ Scotland pp. 20-25.

El- Khawaga, A.S. and Mansour, A.G.M. (2014) 'Promoting productivity of Washington Navel orange trees by using some crop seed sprout extracts, silicon and glutathione' Middle East J. of Applied Sci. 4(3) 779-785.

El-Salhy, A.M., Ibrahim, R.H., Megavver, M.A. and Abd El-Hafiz, G.N. (2017) 'Effect of plant extracts spraying on growth and fruiting of Flame seedless grapevines' Assuit J. Agric. Sci., 48(3):pp. 188-197.

Hegazy, M.U.M. (2015) 'Studies on some treatments to improve the productivity of olive fruits and fruit quality' M. Sc. Thesis Fac. of Agric. Suez Canal Univ.

Kirtikar, K.R. and Basu, B.D. (1984) 'Indian Medicinal plants vol. IV Bishen Singh and Mahendrepal sing' Dehra Dun, pp. 24172426.

Lane, J.H. and Eynon, L (1965) 'Determination of reducing sugars by means of fehlings solution with methylene blue as indicator A.O.A.C' Washington D.C/U.S.A. 
Lee, L.S., Kim, S.H., Kim, Y.B. and Kim, Y.C. (2015) 'Quantitative analysis of major constituents in green tea with different plucking periods and their antioxidant activity 'Molecules, 19(7), 9173-9186.

Martos, M.V., Tolanda, R.N., Juana, F.L. and Jose, A.P. (2007) 'Chemical composition of the essential of oils. Obtained from some spices widely used in Mediterranean region Acta' Chin. Slov. 54:pp. 921-956.

Mnayer, D., Fabiano- Tixier, A.S. Petitcolas, E. Hamioeh, T., Nehme, N. Ferrant, C., Fernanez, X. and Chemat, F. (2014) 'Chemical composition, antibacterial and antioxidant activities of six essentials oils from the Allia Ceae family Moelcules' 19(12):pp. 20034-20053.

Mohamed, Y.A. and Mohamed, H.H. (2013) 'The synergistic effects of using turmeric with various nutrients on fruiting of Sewy date palms' Hort. Science Journal of Suez Canal Univ. 2013, Vol. 1:pp. 287-291.

Peter K.V. (1999) 'Information on turmeric and ginger' Indian species 6 (2, 3): 12- 14.

Refaai, M.M. (2014) 'Response of Zaghloul date palms grown under Minia region conditions to spraying wheat seed sprout extract and nano- boron Stem' Cell 5 (4):pp. 22-28.

Snedecor, G.A.V. and Cochran, G.W. (1980) 'Statistical methods. $7^{\text {th }}$ ED' Iowa State Univ. Press. Ames, Iowa, U. S. A 507.

Srimal, R.C. (1997) 'Turmeric a brief review of medical properties' Filoterapoa, 68 (6):pp. 483-494.

Uwakiem, M.K. (2014) 'The synergistic effect of spraying some plant extracts with some macro and micro nutrients of Thompson seedless grapevines' International Journal of Plant \& Soil Science 3 (10):pp. 12901301 . 